\title{
Pengaruh Lama Perkecambahan Terhadap Total Fenol, Flavonoid, Dan Aktivitas Antioksidan Tepung Kecambah Kacang Tunggak (Vigna unguiculata L. Walp.)
}

\section{Effect of Germination Time on Total Phenolic Content, Total Flavonoid Content, and Antioxidant Activity of Cowpea Sprout Flour (Vigna unguiculata L. Walp.)}

\author{
Amira Putri $^{1}$, Ni Wayan Wisaniyasa ${ }^{1 *}$, I Putu Suparthana ${ }^{1}$ \\ Program Studi Ilmu dan Teknologi Pangan, Fakultas Teknologi Pertanian, Universitas Udayana \\ Kampus Bukit Jimbaran, Badung-Bali \\ *Penulis korespondensi: Ni Wayan Wisaniyasa, Email: wisaniyasa@unud.ac.id,
}

\begin{abstract}
This study aims to determine the effect of germination time on total phenolic content, total flavonoid content, and antioxidant activity of cowpea sprout flour, and to determine which germination time that will give the best result of total phenolic content, total flavonoid content, and antioxidant activity of cowpea sprout flour. The research design used in this study is Completely Randomized Design with five germination times such as $0,12,24,36$, and 48 hours with each treatment was repeated three times. The cowpea sprout flour was tested for total phenolic content, total flavonoid content, and antioxidant activity. The data obtained were analyzed by using Analysis of Variance (ANOVA), and if the treatment had significant effect followed by Duncan's Multiple Range Test (DMRT). The result showed that germination of cowpea had a significant effect on total phenolic content, total flavonoid content, and antioxidant activity. The best germination time was 48 hours that resulted in total phenolic content of $256.16 \mathrm{mg} \mathrm{GAE} / 100 \mathrm{~g}$, total flavonoid content of $29.97 \mathrm{mg} \mathrm{QE} / 100 \mathrm{~g}$, and antioxidant activity $\left(\mathrm{IC}_{50}\right)$ of $5,928.39 \mathrm{mg} / \mathrm{L}$.
\end{abstract}

Keywords : cowpea sprout flour, total phenolic content, total flavonoid content, antioxidant activity

\section{PENDAHULUAN}

Indonesia memiliki berbagai jenis kacang-kacangan yang berpotensi untuk menambah zat gizi dalam diet atau menu sehari-hari (Ekafitri dan Isworo, 2014). Menurut Utomo dan Antarlina (1998), kacang-kacangan merupakan sumber protein nabati yang dapat dimanfaatkan untuk memperbaiki gizi. Salah satu jenis kacang yang dikonsumsi di Indonesia adalah kacang tunggak. Menurut Haliza et al (2007), kacang tunggak memiliki kandungan, protein sebesar 22,9 g/100 g. Kandungan protein kacang tunggak lebih tinggi dibanding kacang hijau
$(22,2 \mathrm{~g} / 100 \mathrm{~g})$, kacang gude $(20,7 \mathrm{~g} / 100 \mathrm{~g})$, dan kacang bogor (16,0 g/100 g).

Selain itu, kacang tunggak juga mengandung fenol dan flavonoid serta memiliki aktivitas antioksidan. Senyawa polifenol memiliki aktivitas antioksidan yang mampu melindungi tubuh dari berbagai penyakit akibat kerusakan oksidatif yang disebabkan oleh senyawa oksigen reaktif (Akagawa dan Suyama, 2001). Menurut Yulistian et al. (2015), ekstrak biji kacang tunggak dalam $80 \%$ aseton mengandung kadar fenolik total sebesar 8.081,4 mg EAG/g, kadar flavonoid total sebesar 33.308,3 mg EK/g, dan aktivitas antioksidan 
sebesar 25.973,3 mg EB/g. Senyawa fenolik pada kacang tunggak adalah asam protekateat, asam $p$-hidroksibenzoat, asam kafeat, asam $p$-kumarat, asam ferulat, asam 2,4-dimetoksibenzoat, dan asam sinamat (Cai et al, 2003).

Meskipun demikian, kacang tunggak masih relatif terbatas dalam pemanfaatannya karena informasi mengenai inovasi dan temuan baru yang dapat menarik konsumen untuk lebih banyak memanfaatkan kacang tunggak sebagai bahan makanan masih belum banyak tersebar dan berkembang. Selain itu pada kacang-kacangan terdapat zat antigizi yaitu penghambat tripsin dan khimotripsin, oligosakarida, polifenol/tanin, asam fitat, serta adanya sifat tidak mudah lunak setelah proses pemasakan (gejala hardto-cook/HTC) yang dapat menghambat dalam konsumsi kacang tunggak. Peningkatan pemanfaatan kacang tunggak antara lain dengan pengolahan secara tradisional melalui fermentasi atau tanpa fermentasi, yaitu dengan cara pengecambahan (Utomo dan Antarlina,1998).

Menurut Copeland dan McDonald (2001) perkecambahan adalah peristiwa tumbuhnya embrio yang dapat menyebabkan pecahnya kulit biji dan tumbuhnya tanaman muda. Beberapa penelitian menunjukkan bahwa perkecambahan mempengaruhi kandungan gizi kecambah serta menurunkan kandungan antigizinya. Menurut Elvira et al. (2019) perkecambahan kacang tunggak selama 24 jam meningkatkan kadar protein dari $26,41 \%$ menjadi $28,18 \%$ dan daya cerna proteinnya dari $45,28 \%$ menjadi $48,45 \%$. Selain itu menurut Ningsih (2007) proses perkecambahan pada kacang tunggak selama 24 jam dapat menurunkan kadar tanin sebesar 22,45\%. Menurut Wisaniyasa et al (2015), perkecambahan kacang gude selama 72 jam juga dapat menurunkan aktivitas anti tripsin sebesar 46\%, dan menurut Fouad dan Rehab (2015) perkecambahan lentil selama 6 hari juga menurunkan kandungan tanin sebesar $59,40 \%$.

Penelitian dengan perlakuan lama perkecambahan dilakukan karena lama perkecambahan dapat pula mempengaruhi kandungan bioaktif. Menurut Asropah et al. (2019), aktivitas antioksidan pada kacang kedelai hitam cenderung meningkat pada perlakuan perkecambahan 24, 32, dan 40 jam, dengan hasil masing-masing 22,34\%, $22,61 \%$, dan $24,51 \%$. Menurut Wisaniyasa $e t$ al. (2017), total fenol, flavonoid, dan aktivitas antioksidan tepung kecambah kacang merah mengalami peningkatan sampai lama perkecambahan 48 jam, dengan hasil masing-masing sebesar 6,33\%, 9,23 $\mathrm{mgQE} / 100 \mathrm{~g}$ bahan, dan 53,91 IC50\%. Menurut Wisaniyasa dan Suter (2016), perlakuan perkecambahan pada kacang merah selama 48 jam dapat meningkatkan kapasitas antioksidan dari $85,49 \mathrm{mg} / \mathrm{kg}$ menjadi 140,34 mg/kg.

Dalam penelitian ini digunakan perlakuan lama perkecambahan dari 0 hingga 
48 jam. Menurut Wisaniyasa et al. (2017), pada tepung kecambah kacang merah total fenol meningkat dari 4,46\% menjadi $6,33 \%$ pada perlakuan lama perkecambahan 0 hingga 48 jam, namun mengalami penurunan hingga $5,21 \%$ dan $4,63 \%$ pada perlakuan lama perkecambahan 60 dan 72 jam. Total flavonoid meningkat dari $1,68 \mathrm{mgQE} / 100 \mathrm{~g}$ bahan menjadi 9,23 mgQE/100g bahan pada perlakuan lama perkecambahan 0 hingga 48 jam, namun mengalami penurunan hingga 3,70 $\mathrm{mgQE} / 100 \mathrm{~g}$ bahan dan 3,36 mgQE/100g bahan pada perlakuan lama perkecambahan 60 dan 72 jam. Aktivitas antioksidan menurun dari 65,10 IC50\% menjadi 53,91 IC50\% pada perlakuan lama perkecambahan 0 hingga 48 jam, namun mengalami peningkatan hingga 55,85 IC50\% dan 56,64 IC50\% pada perlakuan lama perkecambahan 60 dan 72 jam.

Kecambah segar mempunyai sifat mudah rusak dan terbatas dalam variasi konsumsinya, sehingga kecambah dapat diolah menjadi tepung kecambah sebagai alternatif pengawetan kecambah (Meisara dan Nurhidajah, 2012). Tepung memiliki keunggulan yaitu dapat lebih tahan disimpan, mudah dicampur dengan tepung lain (komposit), diperkaya zat gizi (fortifikasi), mudah dibentuk, dan lebih cepat dimasak (Widowati, 2009)

Sampai saat ini belum ada penelitian mengenai pengaruh lama waktu perkecambahan terhadap total fenol, flavonoid, dan aktivitas antioksidan tepung kecambah kacang tunggak. Oleh karena itu, penelitian ini dilakukan dengan tujuan untuk mengetahui pengaruh lama perkecambahan terhadap total fenol, flavonoid, dan aktivitas antioksidan tepung kecambah kacang tunggak, dan mengetahui lama perkecambahan yang tepat sehingga dihasilkan tepung kecambah kacang tunggak dengan total fenol, flavonoid, dan aktivitas antioksidan terbaik.

\section{METODE PENELITIAN}

\section{Tempat dan Waktu}

Penelitian ini dilaksanakan di Laboratorium Pengolahan Pangan dan Laboratorium Analisis Pangan Fakultas Teknologi Pertanian Universitas Udayana. Waktu pelaksanaan penelitian mulai bulan November 2019 sampai Januari 2020.

\section{Bahan dan Alat}

Bahan utama yang digunakan dalam penelitian adalah kacang tunggak (Vigna unguiculata L.Walp) yang diperoleh dari Pasar Senggol Jimbaran, Bali. Bahan kimia yang digunakan untuk analisis adalah metanol $85 \%$ (Merck), $\mathrm{Na}_{2} \mathrm{CO}_{3}$ (Merck), reagen Folin Ciocalteu (Merck), asam galat (Sigma), aquades, etanol 50\% (Merck), $\mathrm{AlCl}_{3}$ (Merck), kuersetin (Sigma), DPPH (Himedia), methanol PA (Merck).

Alat yang digunakan pada penelitian ini adalah waskom, wadah plastik, spatula, aluminium foil, botol kaca berwarna gelap, ayakan 60 mesh, blender (Cosmos), timbangan analitik (Shimadzu ATY224), oven 
(Blue M), loyang, spektrofotometer (Biochrom S26), vortex (Maxi Mix II Type 37600 Mixer), sentrifus (Damon/IEC Division), tabung sentrifus, pipet mikro (Accumax PRO), tip, pipet tetes, tabung reaksi (Pyrex), labu ukur (Pyrex), gelas beker (Herma), gelas ukur (Pyrex), dan corong kaca.

\section{Rancangan Percobaan}

Penelitian ini dilakukan menggunakan metode eksperimen dengan Rancangan Acak Lengkap (RAL) dengan perlakuan lama perkecambahan P0 (0 jam), P1 (12 jam), P2 (24 jam), P3 (36 jam), dan P4 (48 jam). Masing-masing perlakuan diulang sebanyak 3 kali sehingga diperoleh 15 unit percobaan. Data yang diperoleh dari hasil penelitian dianalisis dengan sidik ragam (ANOVA) dan apabila perlakuan berpengaruh terhadap variable maka dilanjutkan dengan uji Duncan's Multiple Range Test (DMRT) (Gomez dan Gomez, 1995).

\section{Pelaksanaan Penelitian}

Penelitian ini dilakukan dengan dua tahap. Tahap pertama adalah pembuatan kecambah kacang tunggak. Tahap kedua adalah pembuatan tepung kecambah kacang tunggak. Tahap pertama yaitu pembuatan kecambah kacang tunggak diawali dengan menyortasi kacang tunggak yang layak untuk digunakan dari kotoran-kotoran dan kacang yang rusak, kemudian ditimbang sebanyak 150 g. Kacang tunggak direndam dengan air (kacang : air $=1: 3$ ) selama 8 jam dan ditiriskan. Wadah yang digunakan yaitu keranjang plastik dengan beralaskan daun pisang. Kacang tunggak yang telah ditiriskan diletakkan ke dalam wadah dengan ditutup daun pisang dan dikecambahkan selama 0 , 12, 24, 36, dan 48 jam dengan dipercik air 10 ml tiap 12 jam. Perlakuan lama waktu 0 jam tidak dikecambahkan.

Tahap kedua yaitu pembuatan tepung kecambah kacang tunggak diawali dengan pengovenan kecambah kacang tunggak dengan suhu $50^{\circ} \mathrm{C}$ selama 24 jam. Kecambah kacang tunggak yang telah dioven kemudian diblender, lalu diayak menggunakan ayakan 60 mesh.

\section{HASIL DAN PEMBAHASAN}

Hasil analisis total fenol, flavonoid, dam aktvitas antioksidan tepung kecambah kacang tunggak dapat dilihat pada Tabel 1.

\section{Total Fenol}

Hasil analisis menunjukkan bahwa perkecambahan berpengaruh nyata $(\mathrm{P}<0,05)$ terhadap total fenol tepung kecambah kacang tunggak. Tabel 1 menunjukkan bahwa total fenol tepung kecambah kacang tunggak mengalami peningkatan seiring meningkatnya lama perkecambahan. Total fenol tepung kecambah kacang tunggak dengan perlakuan lama perkecambahan selama 0 jam adalah sebesar 100,55 $\pm 0,68$ mg EAG/100 g dan mengalami peningkatan hingga menjadi sebesar $256,16 \pm 1,57 \mathrm{mg}$ EAG/100 g pada lama perkecambahan selama 48 jam. Hasil ini serupa dengan 
penelitian Fouad dan Rehab (2015) yang menyatakan bahwa perkecambahan lentil dapat meningkatkan total fenol dari $1.341,13 \pm 26,72 \mathrm{mg} / 100 \mathrm{~g}$ pada lama perkecambahan selama 0 hari menjadi $1.510,10 \pm 9,81 \mathrm{mg} / 100 \mathrm{~g}$ pada lama perkecambahan selama 6 hari. Hasil ini juga serupa dengan penelitian Wisaniyasa, et al. (2017) yang menyatakan bahwa perkecambahan kacang merah meningkatkan total fenol dari $4,46 \%$ pada lama perkecambahan selama 0 jam menjadi 6,33\% pada lama perkecambahan selama 48 jam.

Hal ini dapat disebabkan karena selama proses perkecambahan terjadi proses biosintesis senyawa fenolik sebagai bentuk pertahanan diri bagi kecambah. (Randhir et al., 2004). Perkecambahan kacang (Phaseolus vulgaris L. varietas La Granja) dapat meningkatkan kandungan senyawa fenolik yaitu asam $p$-hidroksibenzoat, $p$ hidroksibenzoat aldehida, asam vanilat, vanilat aldehida, asam trans p-kumarat, derivatif asam trans $p$-kumarat, asam trans ferulat, asam cis ferulat, derivatif asam cis ferulat, kuersetin-3-rutinosida, kuersetin-3rhamnosida, kaempferol-3-rutinosida, dan kaempferol-3-gluikosida (López-Amorós et al, 2006). Menurut Naikoo et al (2019), fenol dapat melindungi tanaman dari radiasi sinar ultraviolet, logam berat, kekeringan, suhu dingin, dan kekurangan nutrisi.

Tabel 1. Hasil analisis total fenol, total flavonoid, total tanin, dan aktivitas antioksidan tepung kecambah kacang tunggak

\begin{tabular}{cccc}
\hline $\begin{array}{c}\text { Lama } \\
\text { Perkecambahan } \\
(\text { Jam })\end{array}$ & $\begin{array}{c}\text { Total Fenol } \\
\text { EAG/100 g) }\end{array}$ & $\begin{array}{c}\text { Total Flavonoid } \\
(\mathbf{m g} \text { EQ/100 g) }\end{array}$ & $\begin{array}{c}\text { Aktivitas } \\
\text { Antioksidan } \\
(\%)\end{array}$ \\
\hline 0 & $100,55 \pm 0,68 \mathrm{e}$ & $13,24 \pm 1,16 \mathrm{e}$ & $22,24 \pm 1,44 \mathrm{e}$ \\
12 & $123,62 \pm 1,25 \mathrm{~d}$ & $17,78 \pm 0,84 \mathrm{~d}$ & $29,65 \pm 1,06 \mathrm{~d}$ \\
24 & $181,51 \pm 1,41 \mathrm{c}$ & $20,46 \pm 0,44 \mathrm{c}$ & $33,78 \pm 1,39 \mathrm{c}$ \\
36 & $208,11 \pm 0,61 \mathrm{~b}$ & $22,53 \pm 1,33 \mathrm{~b}$ & $39,00 \pm 0,57 \mathrm{~b}$ \\
48 & $256,16 \pm 1,57 \mathrm{a}$ & $29,97 \pm 0,91 \mathrm{a}$ & $53,08 \pm 0,77 \mathrm{a}$
\end{tabular}

Keterangan: Huruf yang sama di belakang nilai rata-rata pada kolom yang sama menunjukkan perlakuan berbeda tidak nyata $(\mathrm{P}>0,05)$.

\section{Total Flavonoid}

Hasil analisis menunjukkan bahwa perkecambahan berpengaruh nyata $(\mathrm{P}<0,05)$ terhadap total flavonoid tepung kecambah kacang tunggak. Tabel 1 menunjukkan total flavonoid tepung kecambah kacang tunggak mengalami peningkatan seiring meningkatnya lama perkecambahan. Total flavonoid tepung kecambah kacang tunggak dengan perlakuan lama perkecambahan selama 0 jam adalah sebesar 13,24 \pm 1,16 mg EQ/100 g dan mengalami peningkatan hingga menjadi sebesar 29,97 $\pm 0,91$ 
EQ/100 g. Hasil ini serupa dengan penelitian

Fouad dan Rehab (2015) yang menyatakan bahwa perkecambahan lentil dapat meningkatkan total flavonoid dari $398,33 \pm 17,06 \mathrm{mg} / 100 \mathrm{~g}$ pada lama perkecambahan selama 0 hari menjadi $496,21 \pm 10,03 \mathrm{mg} / 100 \mathrm{~g}$ pada lama perkecambahan selama 6 hari.

Menurut Ti et al (2014) selama perkecambahan jalur metabolit fenilpropanoid dapat mengaktivasi jalur pembentukan flavonoid, dan saat itu pula ester asetil CoA yang akan diubah menjadi flavonoid dihasilkan oleh senyawa-senyawa antara. Hal ini menyebabkan total flavonoid dapat semakin meningkat. Menurut Ferreyra et al (2012) jalur fenilpropanoid dapat mengubah fenilalanin menjadi senyawa $p$ kumaril CoA yang kemudian akan masuk ke jalur biosintesis flavonoid. Menurut bagan oleh Nakatsuka et al (2012), reaksi antara $p$ kumaril CoA dan malonil CoA dapat menghasilkan senyawa golongan flavonoid antara lain flavon, flavonol, 3-deoksi antosianin, dan 3-hidroksi antosianin. Malonil CoA merupakan senyawa yang berasal dari reaksi antara asetil CoA dan $\mathrm{CO}_{2}$, yang dikatalis oleh enzim asetil CoA karboksilase (Stafford, 1990).

\section{Aktivitas Antioksidan}

Hasil analisis menunjukkan bahwa perkecambahan berpengaruh nyata $(\mathrm{P}<0,05)$ terhadap aktivitas antioksidan tepung kecambah kacang tunggak. Tabel 1 menunjukkan aktivitas antioksidan tepung kecambah kacang tunggak mengalami peningkatan seiring meningkatnya lama waktu perkecambahan. Aktivitas antioksidan tepung kecambah kacang tunggak dengan perlakuan lama perkecambahan selama 0 jam adalah sebesar $22,24 \pm 1,44 \%$ dan mengalami peningkatan hingga menjadi sebesar 53,08 $\pm 0,77 \%$ pada lama perkecambahan selama 48 jam. Hasil ini serupa dengan penelitian Fouad dan Rehab (2015) yang menyatakan bahwa perkecambahan lentil dapat meningkatkan aktivitas antioksidannya dari 40,76 $\pm 7,2 \%$ pada lama perkecambahan selama 0 hari menjadi $62,19 \pm 6,2 \%$ pada lama perkecambahan selama 6 hari.

Selama perkecambahan aktivitas antioksidan dapat meningkat seiring dengan meningkatnya kandungan senyawa fenolik. Hal ini dapat disebabkan karena pada struktur kimianya, senyawa fenolik mempunyai gugus hidroksil yang dapat berperan sebagai penangkap radikal bebas (Uchegbu dan Ishiwu, 2016). Radikal bebas dapat berubah menjadi radikal yang stabil karena senyawa fenol mendonorkan protonnya (Tursiman et al, 2012).

Berdasarkan hasil analisis aktivitas antioksidan, perlakuan lama perkecambahan selama 48 jam memiliki persentase aktivitas antioksidan tertinggi sehingga perlakuan ini dipilih untuk diuji penentuan $\mathrm{IC}_{50}$.

Dari hasil analisis regresi linier, didapat nilai $\mathrm{IC}_{50}$ sebesar 5.928,39 mg/L. Menurut penggolongan aktivitas antioksidan 
oleh Molyneaux (2004) dalam Bahriul (2014), aktivitas antioksidan tepung kecambah kacang tunggak dinyatakan sangat lemah karena memiliki nilai $\mathrm{IC}_{50}$ di atas $200 \mathrm{ppm}$.

\section{KESIMPULAN DAN SARAN}

\section{Kesimpulan}

Perkecambahan kacang tunggak berpengaruh nyata terhadap total fenol, flavonoid, dan aktivitas antioksidan. Lama perkecambahan kacang tunggak yang terbaik adalah 48 jam, yang menghasilkan total fenol sebesar 256,16 mg EAG/100 g, total flavonoid sebesar 29,97 mg EQ/100g, dan aktivitas antioksidan $\left(\mathrm{IC}_{50}\right)$ sebesar $5.928,39 \mathrm{mg} / \mathrm{L}$.

\section{Saran}

Kacang tunggak dapat dikecambahkan selama 48 jam agar diperoleh total fenol, flavonoid, dan aktivitas antioksidan tebaik, untuk kemudian diolah menjadi tepung agar dapat dimanfaatkan sebagai produk pangan fungsional.

Tepung kecambah kacang tunggak dapat dikombinasikan dengan bahan pangan lain dan diolah dengan berbagai variasi teknik pengolahan agar dapat dihasilkan produk pangan fungsional yang memiliki kandungan komponen bioaktif yang tinggi.

\section{DAFTAR PUSTAKA}

Akagawa, M, dan K. Suyama. 2001. Amine Oxidase Like Activity of Polyphenols
Mechanism and Properties. Eur. J. Biochem. 268: 1953-1963.

Asropah, S., Nurrahman, dan W. Hersoelistyorini. 2019. Pengaruh Lama Perkecambahan Terhadap Rendemen, Kadar Antosianin, Vitamin E dan Aktivitas Antioksidan Kecambah Kedelai Hitam. Jurnal Pangan dan Gizi. 9(1): 39 52.

Bahriul, P., N. Rahman, dan A. W. M. Diah. 2014. Uji Aktivitas Antioksidan Ekstrak Daun Salam (Syzygium polyanthum) dengan Menggunakan 1,1-Difenil-2Pikrilhidrazil. J. Akad. Kim. 3(3): 143149.

Cai, R. N. S. Hettiarchchy, dan M. Jalaluddin. 2003. High-Performance Liquid Chromatography Determination of Phenolic Constituents in 17 Varietes of Cowpea. J. Agric. Food Chem. 51(6): 1623-1627.

Copeland, O.L dan M.B. McDonald. 2001. Principles of Seed Science and Technology 4th Edition. Springer Science-Business Media, LLC. New York.

Ekafitri, R. dan R.Isworo. 2014. Pemanfaatan Kacang-Kacangan sebagai Bahan Baku Sumber Protein Untuk Pangan Darurat. PANGAN. 23(2) : 134-145.

Elvira, N., N. W. Wisaniyasa, N. M. Indri Hapsari A. 2019. Studi Sifat Kimia, Fungsional, dan Daya Cerna Protein Tepung Kecambah Kacang Tunggak (Vigna unguiculata (L.) Walp). Media Ilmiah Teknologi Pangan (Scientific Journal of Food Technology). 6(1): 43-53

Ferreyra, M. L. F., S. P. Rius, dan P. Casati. 2012. Flavonoids: Biosynthesis, Biological Functions, and Biotechnological Applications. Frontiers in Plant Science. 3(222): 1-15

Fouad, A. A. dan F. M. A Rehab. 2015. Effect of Germination Time on Proximate Analysis, Bioactive Compounds, and Antioxidant Activity of Lentil (Lens culinaris Medik.) Sprouts. Acta Sci. Pol. Technol Aliment. 14(3): 233-246.

Gomez, K.A. dan A. A. Gomez. 1995. Prosedur Statistik untuk Penelitian Pertanian. Diterjemahkan oleh E. Sjamsuddin dan J. S. Baharsjah. UI Press. Jakarta.

Haliza, W., E. Y. Purwani, dan R. Thahir. 2007. Pemanfaatan Kacang-Kacangan 
Lokal Sebagai Substitusi Bahan Baku Tempe dan Tahu. Buletin Teknologi Pascapanen Pertanian. 3: 1-8.

López-Amorós, M. L., T. Hernández, dan I. Estrella. 2006. Effect of Germination on Legume Phenolic Compounds and Their Antioxidant Activity. Journal of Food Composition and Analysis. 19 :277-283.

Meisara, R. dan Nurhidajah. 2012. Aktivitas Antioksidan, Karakteristik Kimia, dan Organoleptik Tepung Kecambah Kedelai (Glycine max) dengan Berbagai Variasi Pengolahan. Jurnal Pangan dan Gizi.3(6): 1-8.

Naikoo, M.I., M. I. Dar, F. Raghib, H. Jaleel, B. Ahmad, A. Raina, F. A. Khan, dan F. Naushin. 2019. Role and Regulations on Plant Phenolics in Abiotic Stress Tolerance: An Overview. In Plant Signaling Molecules. M.I.R. Khan, P. S. Reddy, A. Ferrante, dan N. A. Khan (Eds.). Woodhard Publishing. Duxford. p. 157-168.

Nakatsuka, T., M. Saito, E. Yamada, K. Fujita, Y. Kakizaki, dan M. Nishihara. 2012. Isolation and Characterization of GtMYBP3 and GtMYBP4, Orthologues of R2R3-MYB Transcription Factors that Regulate Early Flavonoid Biosynthesis, in Gentian Flowers. Journal of Experimental Botany. 63(18): 65056517.

Ningsih, W. 2007. Evaluasi Senyawa Fenolik (Asam Ferulat dan Asam p-Kumarat) pada Biji, Kecambah dan Tempe Kacang Tunggak (Vigna unguiculata). Skripsi. Tidak dipublikasikan. Institut Pertanian Bogor. Bogor.

Randhir, R. Y.T. Lin, dan K. Shetty. 2004. Stimulation of Phenolics, Antioxidant and Antimicrobial Activity in Dark Germinated Mung Bean Sprouts in Response to Peptide and Phytochemical Elicitors. Process Biochemistry. 39 (2004): 637-646.

Stafford, H. A. 1990. Flavonoid Metabolism. CRC Press, Inc. Florida

Ti, H., R. Zhuang, M. Zhang, Q. Li, Z. Wei, Y. Zhang, X. Tang, Y. Deng, L. Liu, dan Y. Ma. 2014. Dynamic Changes in the Free and Bound Phenolic Compounds and Antioxidant Activity of Brown Rice at Different Germination Stages. Food Chemistry. 161: 337-344.
Tursiman, P., Ardiningsih, dan R. Nofiani. 2012. Total Fenol Fraksi Etil Asetat dari Buah Asam Kandis (Garcinia dioica Blume). JKK. 1(1):45-48.

Uchegbu, N. N. dan C. N. Ishiwu. 2016. Germinated Pigeon Pea (Cajanus cajan); A Novel Diet for Lowering Oxidative Stress and Hyperglycemia. Food Science and Nutrition. 4(5): 772-777

Utomo, J. K. dan S. S. Antarlina. 1998. Teknologi Pengolahan dan ProdukProduk Kacang Tunggak. Monograf Balitkabi. 3: 120-138.

Widowati, S. 2009. Tepung Aneka Umbi Sebuah Solusi Ketahanan Pangan. Balai Besar Penelitian dan Pengembangan Pascapanen Pertanian dimuat dalam Tabloid Sinar Tani.

Wisaniyasa, N. W., I. K. Suter, Y. Marsono, dan I. N. K. Putra. 2015. Germination Effect on Functional Properties and Antitrypsin Activities of Pigeon Pea (Cajanis cajan (L.) Millsp.) Sprout Flour. Food Science and Quality Management. 43: 79-83.

Wisaniyasa, N. W., dan I. K. Suter. 2016. Kajian Sifat Fungsional dan Kimia Tepung Kecambah Kacang Merah (Phaseolus vulgaris L.). Media Ilmiah Teknologi Pangan. 3(1): 26-34.

Wisaniyasa, N. W., N.L.P.T. Darmayanti, dan I.G.A.K.D. Puspawati. 2017. Kajian Total Fenol, Flavonoid, dan Aktivitas Antioksidan Kacang Merah (Phaseolus vulgaris L.) pada Berbagai Lama Waktu Perkecambahan. Seminar Nasional Sains dan Teknologi IV (SENASTEK IV), 2017.

Yulistian, D. E., E. P. Utomo, S. M. Ulfa, dan E. Yusnawan. 2015. Studi Pengaruh Jenis Pelarut terhadap Hasil Isolasi dan Kadar Senyawa Fenolik dalam Biji Kacang Tunggak. Kimia Student Journal. 1(1): 819-825. 